\title{
Adherence of family medicine physicians to therapy based on medicinal plants in a Greater Lisbon sample: a first survey
}

\author{
Adesão de médicos de medicina familiar à terapia baseada em plantas medicinais, numa \\ amostra da Grande Lisboa: uma primeira pesquisa
}

\author{
Alda PS Oliveira ${ }^{1,2}$, Marta Geraldes², Ana Díaz-Lanza ${ }^{3}$, Ilona Kovacs ${ }^{4}$, M Céu Costa ${ }^{2}$ \\ ${ }^{1}$ Faculty of Medicine, University of Lisbon, Lisbon, Portugal \\ ${ }^{2}$ CBIOS, the University Lusofona's Research Center for Biosciences and Health Technologies, Av Campo Grande 376 \\ Lisboa (1749 024) Portugal \\ ${ }^{3}$ Departamento de Ciencias Biomédicas, Facultad de Farmacia, Universidad de Alcalá, Madrid, Spain \\ ${ }^{4}$ Research Center in Economic and Organizational Sociology, Lisbon School of Economics \& Management, University of \\ Lisbon, Portugal \\ Email: alda_pereira@hotmail.com
}

\begin{abstract}
The aim of this study was to verify the adherence of general practitioners to the therapy with medicinal plants, and the constraint underlying the acceptance of their therapeutic value and use in clinical practice.

An observational-transversal exploratory study was carried out through the application of a questionnaire to physicians of the National Health System in the Greater Lisbon area. A total of 80 valid questionnaires were obtained. The doctors' ages ranged from 29 to 64 years $(51.85 \pm 9.95), 71.4 \%$ of whom were female, and $52.6 \%$ with more than 30 years of clinical practice. There was a general lack of knowledge regarding phytotherapy legislation. Of the sample of physicians interviewed, it was verified that $33.8 \%$ never and $28.85 \%$ only a few times recommended/prescribed any type of herbal therapy. Concerning their own use, $61.25 \%$ indicated that they never, and $21.08 \%$ rarely, used herbal medicines, primarily as self-medication. There is a poor adherence on the use of herbal medicines or medicinal plants by physicians. This underuse may underlie the lack of training on both herbal medicinal products and legislative aspects more than rejection of this therapeutic approach. Education in phytotherapy can prevent misuse and reduce risks linked to herbal-drug interactions, dealing with patient's preference in behalf of a healthy physician-patient interaction.
\end{abstract}

Keywords: Phytomedicine; Herbal medicine; Family Medicine; Medical Education; Traditional Herbal Medicine.

\section{Resumo}

O objetivo deste trabalho foi o de averiguar a adesão de médicos de Medicina Familiar à terapia com plantas medicinais e os constrangimentos subjacentes à aceitação do seu valor terapêutico e sua utilização na prática clínica.

Foi realizado um estudo exploratório observacional-transversal, através da aplicação de questionário a médicos do Sistema Nacional de Saúde, na Grande Lisboa.

Obtiveram-se um total de 80 questionários válidos. As idades foram compreendidas dos 29 aos 64 anos (M $\pm \mathrm{DP}: 51,85 \pm$ 9,95), 71,4\% do género feminino, 52,6\% com mais de 30 anos de prática clinica. Constatou-se desconhecimento geral sobre a legislação de fitoterapia. Verificou-se que da amostra de médicos inquiridos, 33,8\% nunca e 28,85\% poucas vezes, recomendou / prescreveu qualquer tipo de terapia à base de plantas. Do mesmo modo na utilização própria (61,25\% referiu que nunca e $21,08 \%$ poucas vezes utilizou medicamentos à base de plantas para si próprio e, quando o fez, fê-lo por automedicação).

Há uma adesão fraca à utilização de terapia baseada em plantas medicinais pelos médicos. A esta fraca utilização está subjacente não tanto a rejeição desta abordagem terapêutica, mas sobretudo, a carência de formação tanto sobre medicamentos à base de plantas medicinais como sobre aspetos legislativos. A necessidade de informação é revelada pelos médicos. A educação em fitoterapia pode prevenir a utilização inapropriada e riscos ligados a interações medicamentosas, ao mesmo tempo considerando as preferências percebidas do utente e favorecendo uma saudável relação clínica.

Palavras-chave: Medicamento à base de plantas, Fitoterapia; Medicina familiar; Educação médica; Medicamento tradicional à base de plantas 


\section{Introduction}

Medicinal plants have long been used in the search for benefits for human health. In the current regulatory context, medicinal plants can be conveyed in various forms available on the market, such as herbal medicine products (HMP), traditional herbal medicines, medicinal herbs and dietary supplements based on botanicals. Many of these over-the-counter products do not require a prescription, and as they available to patients for selfmedication, they may therefore be used improperly (1) Health professionals have a leading role in guiding patients about therapeutic options and should have adequate knowledge of the available therapies to be able to advise the patient in order to minimize the risks associated with self-medication or inappropriate counselling. Previous work has shown the preference of patients to treat ailments with herbal products and a discrepancy between adherence and the recommendation of the use of medicinal plants in medical therapeutics (2).

In Portugal HMP are regulated through the Medicines Regulatory Statute (3) and marketed in accordance with the rules defined and transposed from Directive $2001 / 83$ / EC (4) and the modifications introduced by Directive 2004/27/EC of the European Parliament and European Council (5) as medicinal products for human use, with pharmacological activity and duly sustained clinical efficacy, similar to conventional medicinal products with a synthetic chemical origin. Directive 2004/24/EC (6) has also implemented a simplified registration procedure for Traditional Herbal Medicinal Products (THMP), which plays a very important role in the access to herbals by both health professionals and consumers in the name of the global harmonization of herbal products quality and use.

This Directive introduced the registration procedure for these medicinal products in a simpler and less expensive way. It is intended, mainly, for those products with a long tradition of use in Europe, while providing quality assurance, similar to that required for new medicinal chemical entities. According with EMA (European Medicines Agency) the registration of this new category of HMP is performed without clinical safety tests and clinical trials, which are, however, mandatory under the full marketing authorization procedure for conventional medicines. It also contemplates exclusive and suitable approved indications for traditional use, which are designed to be used without the supervision of a doctor for diagnostic, prescription or treatment monitoring purposes (6). THMPs are recorded in this way with sufficient safety data and plausible evidence, unlike well-established used herbal medicinal products

\section{Introdução}

As plantas medicinais têm sido utilizadas desde longa data na procura de benefícios para a saúde humana. Atualmente, o seu contexto regulamentar disponibiliza no mercado várias formas nas quais as plantas medicinais podem ser veiculadas, como os medicamentos à base de plantas (MBP), os medicamentos tradicionais à base de plantas (MTBP), chás medicinais e suplementos alimentares à base de plantas.

Muitos destes produtos, de venda livre, não são sujeitos a receita médica e encontram-se disponíveis aos pacientes para automedicação, podendo ser inapropriadamente utilizados (1)

Os profissionais de saúde têm um papel preponderante na orientação dos pacientes sobre as opções de saúde, terapêuticas ou outras, devendo ter para tal conhecimentos adequados sobre as terapêuticas disponíveis no sentido de estar apto ao aconselhamento do paciente com vista a minimizar os riscos associados a uma automedicação ou orientação inapropriada.

Trabalhos anteriores evidenciam a preferência dos pacientes em se tratar com produtos à base de plantas e uma discrepância entre a adesão e a recomendação da utilização de plantas medicinais na terapêutica médica (2).

Em Portugal através do Estatuto do Medicamento (3) os medicamentos à base de plantas (MBP) encontram-se regulamentados e são comercializados de acordo com as regras definidas e transpostas da Diretiva 2001/83/ CE (4) e pelas modificações introduzidas pela Diretiva 2004/27/CE do Parlamento e do Conselho (5) como medicamentos para uso humano, com atividade farmacológica e eficácia clínica devidamente sustentada, em semelhança aos medicamentos convencionais com origem em síntese química. Também a Diretiva 2004/24/ CE (6) veio implementar, um procedimento de registo simplificado para os Medicamentos Tradicionais à Base de Plantas (MTBP), os quais desempenham um papel muito importante no acesso aos medicamentos à base de plantas, quer junto dos profissionais de saúde quer dos consumidores, em nome da harmonização global de produtos à base de plantas. Esta Diretiva introduziu o procedimento de registo para estes medicamentos de forma mais simples e menos dispendiosa, sendo destinada principalmente aos que apresentam uma longa tradição de utilização na Europa, fornecendo ao mesmo tempo a garantia de qualidade, à semelhança da exigência com os medicamentos de novas entidades químicas. De acordo com a EMA (Agência Europeia do Medicamento) o registo de MTBP pode ser efetivado sem que tenham sido realizados testes de segurança e ensaios clínicos, os quais, no entanto, são obrigatórios no âm- 
approved only after demonstrating sufficient clinical efficacy and safety data (7).

Other herbal products present in the Portuguese market are food supplements, which are not allowed to claim therapeutic properties, according to European food regulations, and are not included in the pharmaceutical legislation (8).

The diplomas on which these products are governed are the Food Supplements Directive, Directive 2002/46 / EC (9), complemented by an EC Regulation (10), which establishes legislation from the perspective of the consumer and of health professionals. This segment of products represents about $15-20 \%$ of the European market for herbal products, depending on the country (11)

Of course, since quality, safety and efficacy criteria are always present, whether for medicines or food supplements with health claims (physiological effects), it is necessary to know the benefit-risk relationships in the misuse of medicinal plants (12).

The administration of any xenobiotics to the body always requires a benefit-risk analysis, and health professionals have a key role in advising and monitoring their use by the patient. Physicians should be aware of the physiological effects of medicinal plants as well as potential interactions with conventional medicinal products from the point of view of pharmacovigilance and safe use by the patient $(1,12-14)$. Physicians should aim not only to advise about HMPs based on their knowledge and evidence, but also to increase patient confidence and compliance with the available therapeutic options, preventing the occurrence of possible interactions among the patients for herbal products and drugs from chemical synthesis $(13,15,16)$.

Although there is a perception that herbal medicines are safe, in fact this is not always the case when used in concomitance with other prescription medicines $(1,17)$ Thus, optimization of medical care in which physicians are aware of the potential risks and therapeutic benefits of indicating medicinal plants is an attainable goal in the name of good clinical practice (2). The special case of polymedicated patients, such as AIDS patients, shows that unawareness of health professionals about the use of herbal products by their patients (48 in 94, according to Nlooto) may be relevant in the perception and understanding of potential adverse effects that may arise with the concomitant use of therapeutics (18) complementary, and alternative medicines and other practices to combat the disease, with some also using prescribed antiretroviral therapy provided by the public health sector. This study aimed to establish the awareness of public sector biomedical health care providers on the use of traditional, complementary and alterna- bito do procedimento completo de autorização da colocação no mercado para medicamentos convencionais. Também comtempla a possibilidade de indicações terapêuticas exclusivas de utilização tradicional e que foram previamente aprovadas. Estes MTBP foram ainda concebidos para serem utilizados sem a supervisão de um médico para fins de diagnóstico, de prescrição ou de monitorização do tratamento (6).

Os MTBP são registados deste modo com dados de segurança suficientes e evidência plausível, ao contrário dos medicamentos à base de plantas de uso bem estabelecido aprovados apenas após demonstrados os dados de eficácia e segurança clínica suficientes (7).

Outros produtos à base de plantas presentes no mercado português são os suplementos alimentares, os quais não têm permissão de alegar propriedades terapêuticas, e que são regulados de acordo com as diretrizes para os alimentos, não se inserindo na legislação farmacêutica (8). Os diplomas que regem estes produtos são a Diretiva dos Suplementos Alimentares, Diretiva 2002/46/CE (9), e um Regulamento complementar da CE (10), que estabelece a legislação sob a perspetiva do consumidor e dos profissionais de saúde. A este segmento de produtos é atribuída cerca de $15-20 \%$ do mercado europeu de produtos à base de plantas, dependendo do país (11) classified as herbal medicinal products, dietary supplements, cosmetics, foods and beverages depending on the relevant applicable legislation. Many factors are taken into account in the classification of a botanical product (e.g. intended use, labeling, preparations and dosages.

Naturalmente, estando sempre presentes critérios de Qualidade, Segurança e Eficácia, seja para medicamentos, seja para suplementos alimentares com alegações de saúde (eficácia fisiológica), há que conhecer as relações benefício - riscos na utilização indevida de plantas medicinais (12). A administração de quaisquer xenobióticos ao organismo carece sempre de uma análise benefício-risco, tendo os profissionais de saúde um papel essencial no aconselhamento e acompanhamento do seu uso pelo paciente. Os médicos devem estar cientes dos efeitos fisiológicos das plantas medicinais e das potenciais interações com os medicamentos convencionais, sob o ponto de vista da farmacovigilância e da utilização segura pelo paciente $(1,12-14)$ não só para aconselharem os MBP baseados no seu conhecimento e evidência, como para aumentar a confiança e a compliance do paciente com as opções terapêuticas que estão disponíveis, prevenindo a ocorrência de possíveis interações entre os produtos à base de plantas e os fármacos de síntese química $(13,15,16)$.

$\mathrm{Na}$ verdade, apesar de existir uma perceção que os medicamentos à base de plantas são seguros, quando 
tive medicines by HIV-infected patients who also used highly active antiretroviral therapy, and to determine whether this was based on patients seen or cases being reported to them. Potential risks of interactions between the prescribed antiretroviral and non-prescribed medication therapies may pose safety and effectiveness issues in patients using both types of treatment. Methods: A descriptive cross-sectional study, using a researcher administered semi-structured questionnaire, was conducted from June to August 2013 at ten public sector antiretroviral clinics in five regional, three specialised and two district hospitals in eThekwini Health District, South Africa. Questionnaires were administered through face-to face interview to 120 eligible participants consisting of doctors, nurses, pharmacists and post-basic pharmacist assistants in HIV clinical practice. The results are presented as percent or proportion with standard error (SE, beyond their individual use.

Although only $33 \%$ of adults seem to have revealed to doctors the use of herbal medicines (19), it is important that the physician ask the patient about this consumption in order to prevent possible risks of interactions or inappropriate use.

In some countries, physicians generally have a reasonable knowledge and acceptance of herbal medicinal products, although there is a discrepancy between medical adherence and the recommendation of medicinal plants in therapy (20)especially as it relates to safety issues including adverse effects and herb-drug interactions. Most Western-trained physicians are ignorant of the risks and benefits of this healthcare modality and assessment of acceptance and knowledge would identify appropriate intervention strategies to improve physician-patient communication in this area. METHODS: A cross-sectional survey was done using an interviewer-administered pilot tested de novo questionnaire at six public hospitals in Trinidad between May-July 2004. The questionnaire utilized weighed questions to quantify acceptance (maximum score $=14$ points, and the reasons for this phenomenon need to be clarified.

In this context, it seems relevant to evaluate a sample of Portuguese general practitioners and family physicians, performing functions in Health Centres and Family Health Units, and to verify the existing adherence to the use, prescription / recommendation related with herbal products, either whether traditional or not, as well as food supplements containing medicinal plants.

\section{Material and methods}

The study used a questionnaire as a tool to collect information, adapted from a pre-existing and previously usados em concomitância com outros medicamentos de prescrição $(1,17)$ na prática isso nem sempre acontece. Deste modo, a otimização dos cuidados médicos, exige que estes sejam detentores de conhecimento sobre os potenciais riscos e benefícios terapêuticos de plantas medicinais. Este é um objetivo atingível, em nome de uma boa prática clínica (2). O caso especial de pacientes polimedicados, como os pacientes com SIDA, mostra que o desconhecimento dos profissionais de saúde sobre a utilização de produtos à base de plantas por parte dos seus pacientes é elevado (48 em 94, segundo Nlooto), podendo este desconhecimento ser relevante na perceção de eventuais efeitos adversos que possam surgir com a concomitante utilização das terapêuticas (18)complementary, and alternative medicines and other practices to combat the disease, with some also using prescribed antiretroviral therapy provided by the public health sector. This study aimed to establish the awareness of public sector biomedical health care providers on the use of traditional, complementary and alternative medicines by HIV-infected patients who also used highly active antiretroviral therapy, and to determine whether this was based on patients seen or cases being reported to them. Potential risks of interactions between the prescribed antiretroviral and non-prescribed medication therapies may pose safety and effectiveness issues in patients using both types of treatment. Methods: A descriptive cross-sectional study, using a researcher administered semi-structured questionnaire, was conducted from June to August 2013 at ten public sector antiretroviral clinics in five regional, three specialised and two district hospitals in eThekwini Health District, South Africa. Questionnaires were administered through face-to face interview to 120 eligible participants consisting of doctors, nurses, pharmacists and post-basic pharmacist assistants in HIV clinical practice. The results are presented as percent or proportion with standard error (SE, para além do seu uso individual.

Embora apenas 33\% dos adultos pareçam revelaram a utilização de medicamentos à base de plantas (19), é importante que o médico questione o paciente sobre este consumo, a fim de prevenir possíveis riscos de interações ou uso inapropriado.

Em alguns países os médicos apresentam, de forma geral, conhecimentos e aceitação razoável em relação aos produtos medicinais à base de plantas, não obstante haja uma discrepância entre a adesão médica e a recomendação da utilização de plantas medicinais na terapêutica, assim como no conhecimento sobre as mesmas (20)especially as it relates to safety issues including adverse effects and herb-drug interactions. Most Western-trained physicians are ignorant of the risks and benefits of 
tested questionnaire, to anonymously characterize the clinical practice of using herbal products. They were made of the average scores obtained on the Likert scale responses. The statistical methods used were the Student's t-test, the Pearson's correlation or nonparametric equivalent tests, ANOVA and multiple comparison tests and the Chi-square test. Statistical analysis was performed using SPSS software, version 21. For the purpose of statistical inference a significance level of $\alpha$ $=5 \%$ was established, representing a p-value less than alpha, a statistically significant result.

\section{Results}

Of the questionnaires distributed in 38 Health Centers in the Greater Lisbon region, doctors from 28 Centers responded $(87.5 \%)$, and 80 valid questionnaires were obtained, corresponding to the doctors who showed willingness to collaborate in this study (71\%). The sample consisted mainly of female subjects (71.4\%) aged 29-64 years (mean age \pm SD: $51.85 \pm 9.95$ ). Most physicians were in the age group of 50-59 years (58.2\%) and, 52.6\% of them had more than 30 years within the profession. Of the respondents, $55 \%$ had medical specialization (Specialist Degree, 36.3\% in General and Family Medicine) and $12.5 \%$ had completed a Master's Degree. Further, $49.4 \%$ of the respondents were Graduated Assistants, and of these, $16.5 \%$ were at the top of the medical career, as Senior Graduated Assistants. The majority (75.7\%) indicated that they did not practice private medicine.

Regarding professional affiliations, 55.1\% reported working in Family Health Units (USF) and $44.9 \%$ in Personalized Health Care Units (UCSP). Physicians practicing general and family medicine in the Family Health Units were found in lower age groups, compared to the physicians of the UCSP (Mean \pm SD: $47.97 \pm 11.54$ vs. $57.21 \pm 2.59$ years, $\mathrm{p}=0.001)$, with $32.6 \%$ being younger than 40 years, in the USF, while only $2.9 \%$ in the UCSP. The converse was true for the age group above 60 years: $4.7 \%$ in the USF compared to $23.5 \%$ in the UCSP. Most practiced medicine in urban areas.

There is little familiarity with the legislation: $61.5 \%$ of respondents were unaware of the legal recognition of THMP (Figure 1) and $67.3 \%$ were unaware of the difference between well-established Herbal Medicine and Traditional Herbal Medicine (Figure 2).

Our findings reveal that only a minority of physicians consider that there is a benefit in the use of herbal products (Figure 3) and this was consistent with their low recommendation / prescription (Figure 4).

The survey results indicated that most physicians never this healthcare modality and assessment of acceptance and knowledge would identify appropriate intervention strategies to improve physician-patient communication in this area. METHODS: A cross-sectional survey was done using an interviewer-administered pilot tested de novo questionnaire at six public hospitals in Trinidad between May-July 2004. The questionnaire utilized weighed questions to quantify acceptance (maximum score $=14$ points, havendo que esclarecer as razões para este fenómeno.

Neste contexto, parece relevante avaliar uma amostra de médicos portugueses de Medicina Geral e Familiar, a exercer funções em Centros de Saúde e Unidades de Saúde Familiar, e averiguar a adesão existente para a utilização, prescrição / recomendação de produtos à base de plantas, quer sejam medicamentos, tradicionais ou não, assim como suplementos alimentares contendo plantas medicinais.

\section{Material e métodos}

O estudo utilizou como instrumento de recolha de informação um questionário, adaptado de outro pré-existente e previamente testado, para caracterizar de forma anonimizada a prática clínica de utilização de produtos à base de plantas. Foram feitas as médias das pontuações obtidas das respostas em escala de Likert. Os métodos estatísticos utilizados foram o teste de T Student, a correlação de Pearson, ou testes equivalentes não paramétricos, ANOVA e testes de comparações múltiplas e o teste do Qui-quadrado. A análise estatística foi efetuada recorrendo ao software SPSS, versão 21. Para fins de inferência estatística foi estabelecido um nível de significância de $\alpha=5 \%$, representando um valor $\mathrm{p}$ inferior a alfa, um resultado estatisticamente significativo.

\section{Resultados}

Dos questionários distribuídos em 38 Centros de Saúde da região da Grande Lisboa, obteve-se resposta de 28 centros (87,5\%), com 80 questionários válidos, correspondentes aos médicos que mostraram disponibilidade para colaborar neste trabalho (71\%). A amostra é constituída maioritariamente por indivíduos do sexo feminino $(71,4 \%)$ de 29 a 64 anos (média de idades \pm DP: 51,85 $\pm 9,95$ ). A maioria dos médicos encontra-se na faixa etária de 50-59 anos $(58,2 \%)$ e, $52,6 \%$ tem mais de 30 anos de profissão. Dos respondentes, 55\% apresentam especialização médica (grau de especialista, sendo 36,3\% em Medicina Geral e Familiar) e 12,5\% tinham completado um Curso de Mestrado (Grau de Mestre). Verificou-se que 49,4\% 

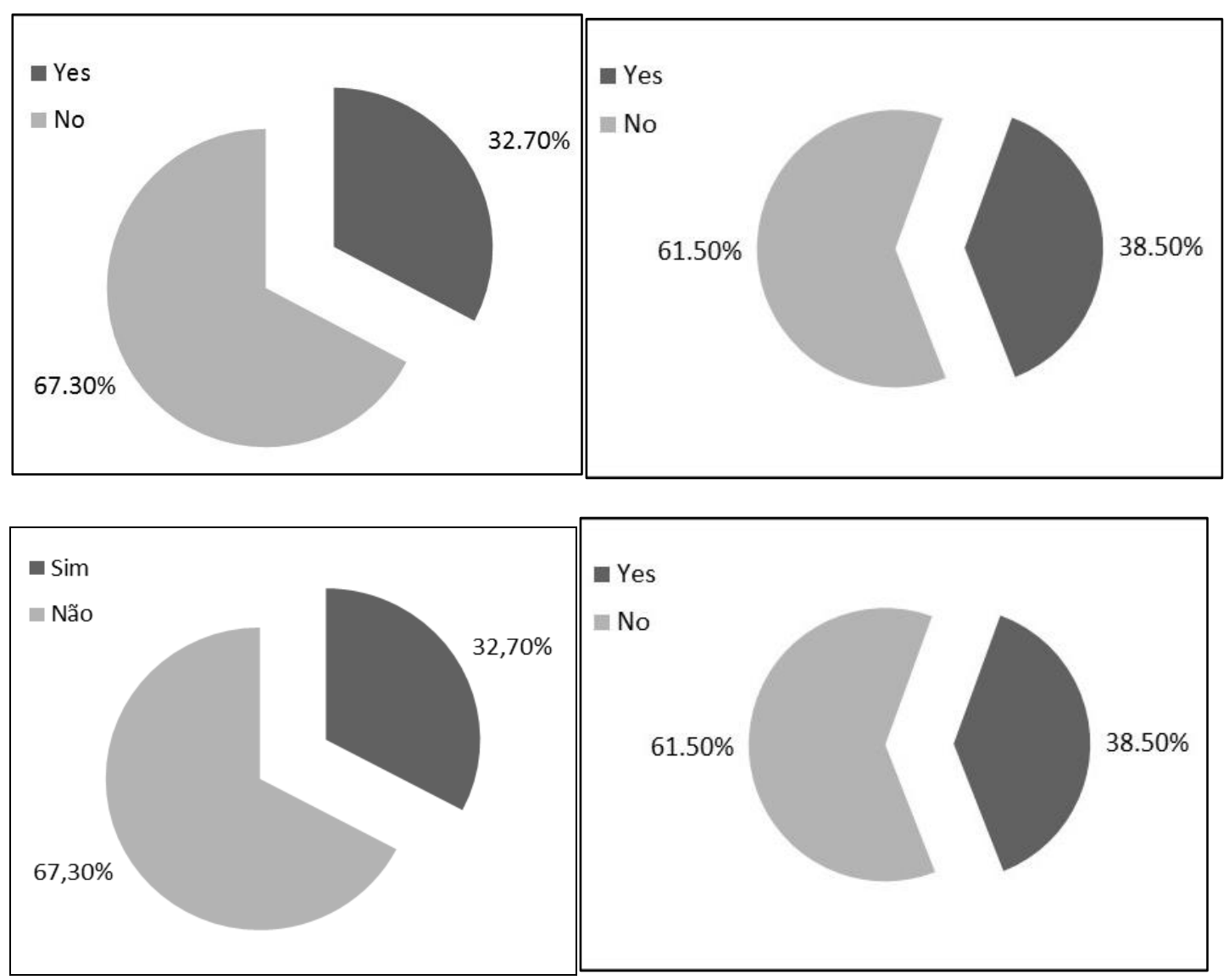

Figure 1 and 2/ Figura 1 e 2 - Doctors' knowledge of European legislation on herbal medicines that introduced traditional herbal medicines. Frequency of recognition of the difference between herbal medicinal product and traditional herbal medicinal product (yes $=32.7 \%$ ) (Figure 1) and of the legal recognition of traditional herbal medicinal products (yes=38.5\%) (Figure 2), yes/no. Frequência dos médicos com conhecimentos sobre legislação europeia dos medicamentos à base de plantas que introduziu os medicamentos tradicionais à base de plantas. Se reconhece a diferença entre medicamento à base de plantas e medicamento tradicional à base de plantas $(\operatorname{sim}=32,7 \%)$ (Figura 1) e se ouviu falar do reconhecimento legal dos medicamentos tradicionais à base de plantas ( $\operatorname{sim}=38,5 \%)$ (Figura 2), sim/não. 

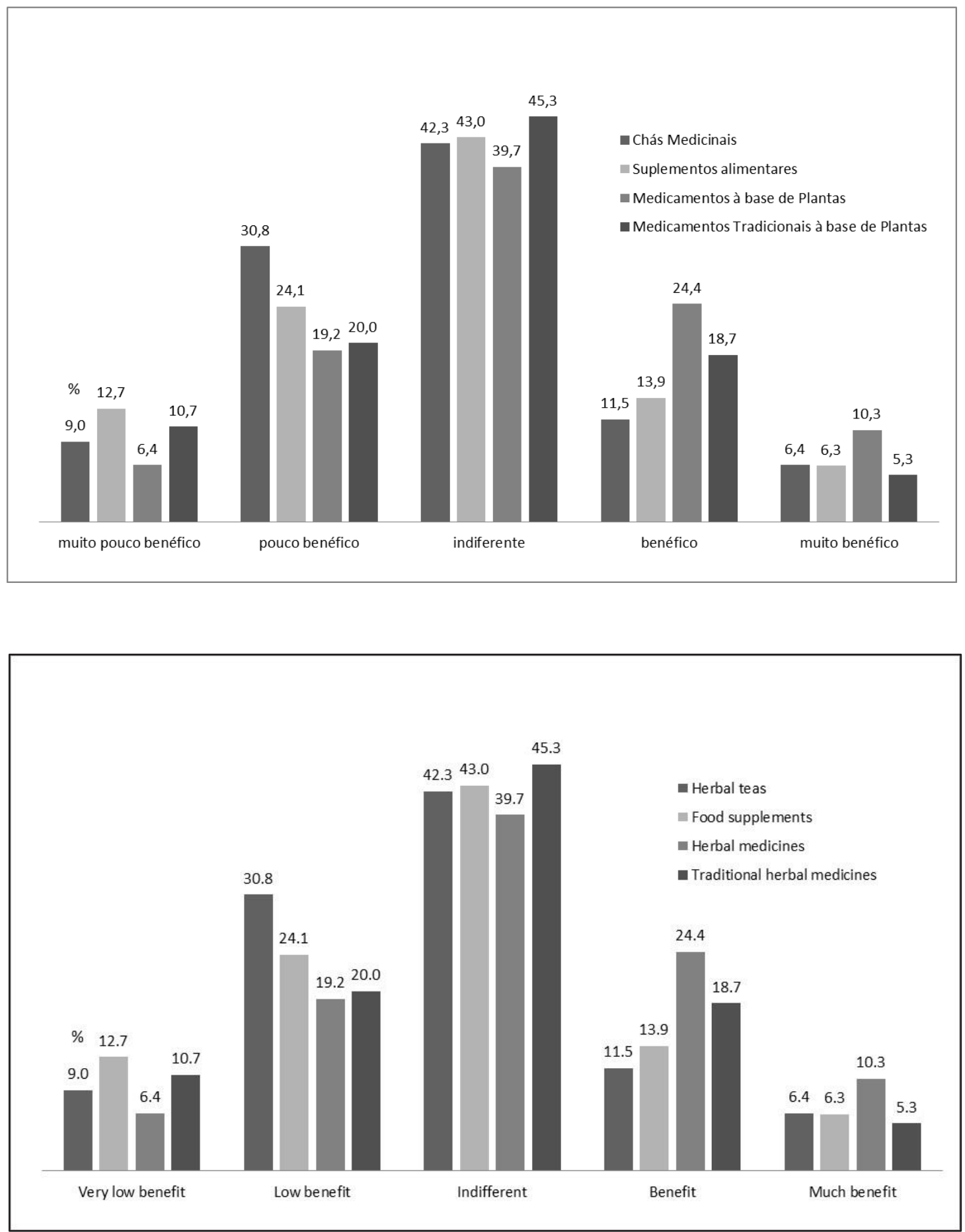

Figure 3/ Figura 3 - Adherence to phytotherapy: opinion of the respondent physicians regarding the potential benefits of using different categories of herbal products/ Adesão à fitoterapia: opinião dos médicos inquiridos, relativamente aos potenciais benefícios de utilização de diferentes categorias de produtos à base de plantas. 
used these products for themselves, and when they did, it was primarily for self-medication (Figures 5 and 6). When evaluating adherence to phytotherapy for their own use, a significant correlation $(r=0.605 ; p<0.0001)$ was observed between the use of the herbal products and its recommendation / prescription. são Assistentes Graduados e que, 16,5\% estão no topo da carreira médica, sendo Assistentes Graduados Séniores. A maioria $(75,7 \%)$ refere não exercer medicina privada. Quanto à vinculação, 55,1\% referem trabalhar em Unidades de Saúde Familiar e 44,9\% em Unidades de Cuidados de Saúde Personalizados (UCSP). Os médicos a exercer Medicina Geral e Familiar nas Unidades de
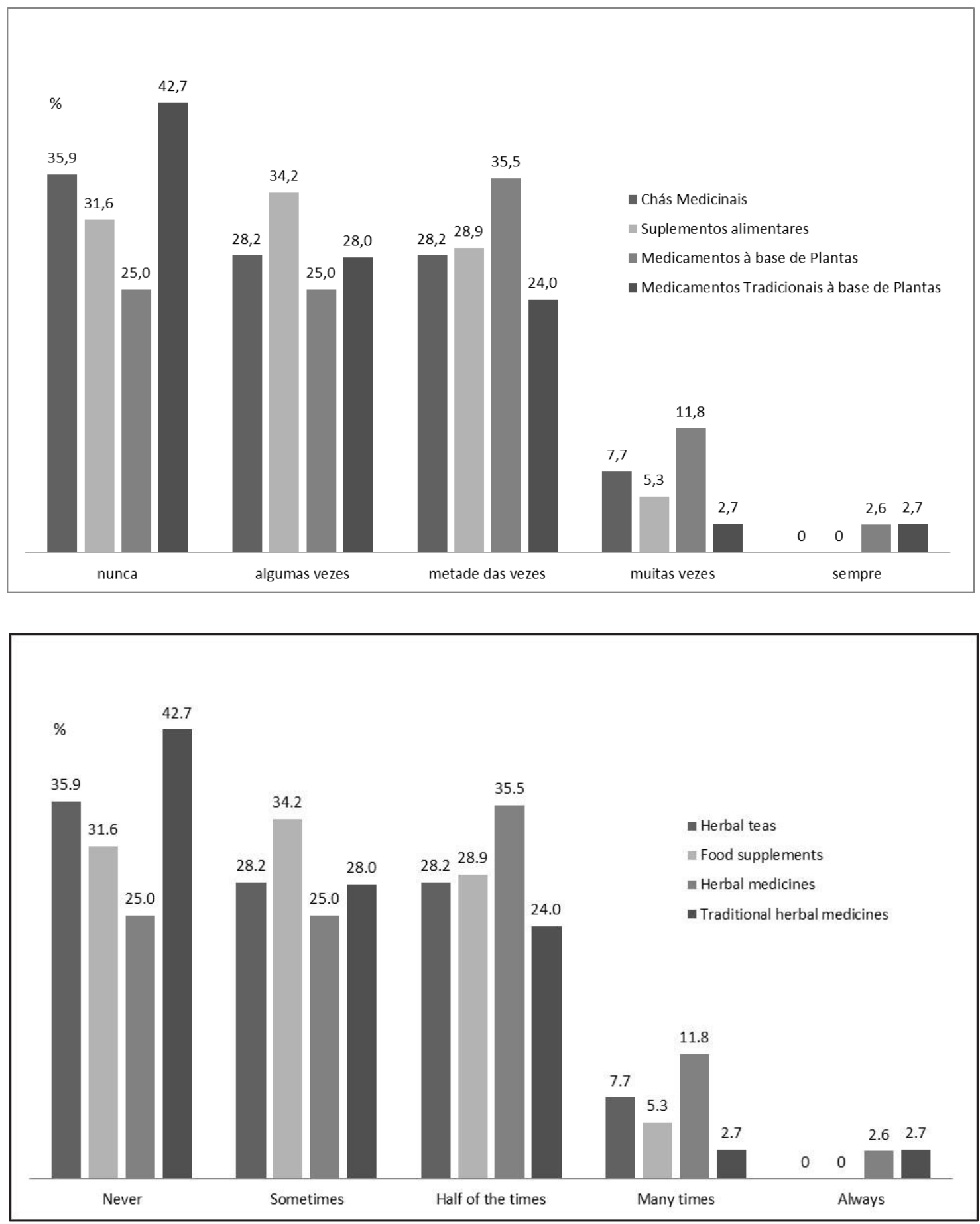

Figure 4/ Figura 4 - Adherence to phytotherapy: Frequency of recommendation / prescription of different categories of herbal products by respondent physicians.

Adesão à fitoterapia: frequência de recomendação / prescrição de diferentes categorias de produtos à base de plantas pelos médicos inquiridos. 
Moreover, the results indicate that the majority of the interviewed physicians never recommended their patients to complementary therapy practitioners (Figure 7).

The results indicate a gender difference in the perception of the effort needed to obtain knowledge related to the herbal products / herbal medicines, with the surveyed women indicating a need for greater effort toward knowledge of the herbals.

There were significant differences regarding the use of herbal products in medical prescription according to the academic degree (graduates: $1.01 \pm 0.72$, specialists: $1.32 \pm 0.83$, masters: $0.36 \pm 0,28$ ), namely between graduates and masters $(\mathrm{p}=0.003$ Tamhane $)$ and between specialists and masters $(\mathrm{p}<0.0001$ Tamhane), the latter being associated with lesser use of herbal medicines.

\section{Discussion}

The medical knowledge of phytotherapy may allow, in addition to the patient's orientation, a better communication between patient / doctor, namely by facilitating the patient to inform their doctor about the use of herbal products such that the doctor can advise the patient about possible adverse effects that, besides being frequent, can be serious and may jeopardize public health $(1,13)$

This aspect is particularly important since most patients do not report this use to the attending physician, nor does the physician question the patient about the use of herbal products (21). In addition, these products are increasingly available and accessible for self-medication $(2,22)$ in the pharmaceutical, herbal and hypermarket markets and may be inappropriately used by patients.

The physician assumes a role with high decision-making power regarding the patient's use of phytotherapy, and this influence is optimized by the trust and support of the doctor-patient relationship. As this professional is understood by the population to be truthful, and has legitimate power in the prescription of medicines, the values and knowledge that the doctors transfer regard the use of the medicines or even the herbal supplements, will be understood by the patient. By opting to follow their advice, the physician's position in relation to herbal medicines will be reflected in the patient's action (2). The discrepancy between medical adherence and the recommendation of the use of medicinal plants in therapy may be based on the lack of knowledge, as verified in studies by several authors $(20,23-25)$. The results of this research also confirm that poor medical adherence, based on the scarce use of herbal products, may be related with the lack of knowledge.
Saúde Familiar (USF) encontram-se em faixas etárias mais baixas, comparadas com os médicos das UCSP (Média \pm DP: $47,97 \pm 11,54$ vs. 57,21 $\pm 2,59$ anos, $p$ $=0,001$ ), sendo que $32,6 \%$ apresentam idades inferiores a 40 anos nas USF, enquanto apenas 2,9\% nas UCSP. $\mathrm{O}$ inverso acontece para faixa etária acima de 60 anos: $4,7 \%$ nas USF comparado com $23,5 \%$ nas UCSP. A maioria exerce medicina em zona urbana.

Verifica-se pouca familiaridade com a legislação: $61,5 \%$ dos inquiridos desconhecem o reconhecimento legal dos medicamentos tradicionais à base de plantas (Figura 1) e 67,3\% desconhecem a diferença entre medicamento de uso bem estabelecido à base de plantas $\mathrm{e}$ medicamento tradicional à base de plantas (Figura 2). Verificou-se que apenas uma minoria dos médicos considera haver benefício na utilização de produtos à base de plantas (Figura 3), sendo coerente com a sua reduzida recomendação / prescrição (Figura 4).

Pode ser observado que a maioria dos médicos nunca utilizou para si próprio estes produtos e, quando o fez, foi para automedicação (Figuras 5 e 6). Ao avaliar a adesão à fitoterapia para uso próprio, verificou-se uma correlação significativa $(r=0,605 ; \mathrm{p}<0,0001)$, entre a utilização própria e a recomendação / prescrição de produtos à base de plantas.

Mais ainda, os resultados indicam que a maioria dos médicos inquiridos nunca recomendou aos seus pacientes o recurso a terapeuta de terapias não convencionais (Figura 7). Os resultados indicam diferença entre os géneros na perceção do esforço necessário para obtenção de conhecimentos relacionados com os produtos / medicamentos à base de plantas, sendo o maior esforço necessário percecionado pelas médicas inquiridas.

Verificaram-se diferenças significativas quanto à utilização de produtos à base de plantas na prescrição médica segundo o grau académico (licenciados: 1,01 $\pm 0,72$; especialistas: $1,32 \pm 0,83$; mestrados: $0,36 \pm 0,28)$ nomeadamente entre licenciados e mestrados $(p=0,003$ Tamhane) e entre especialistas e mestrados ( $p<0,0001$ Tamhane), estando esta última condição associada a um menor uso de medicamentos à base de plantas.

\section{Discussão}

O conhecimento médico de fitoterapia, pode permitir, além da devida orientação do paciente, uma melhor comunicação entre médico / paciente, nomeadamente facilitando que o paciente informe o médico sobre a utilização de produtos à base de plantas, bem como que o médico alerte o paciente sobre efeitos adversos possíveis que, além de frequentes, podem ser graves, pondo em risco a Saúde Pública $(1,13)$ 

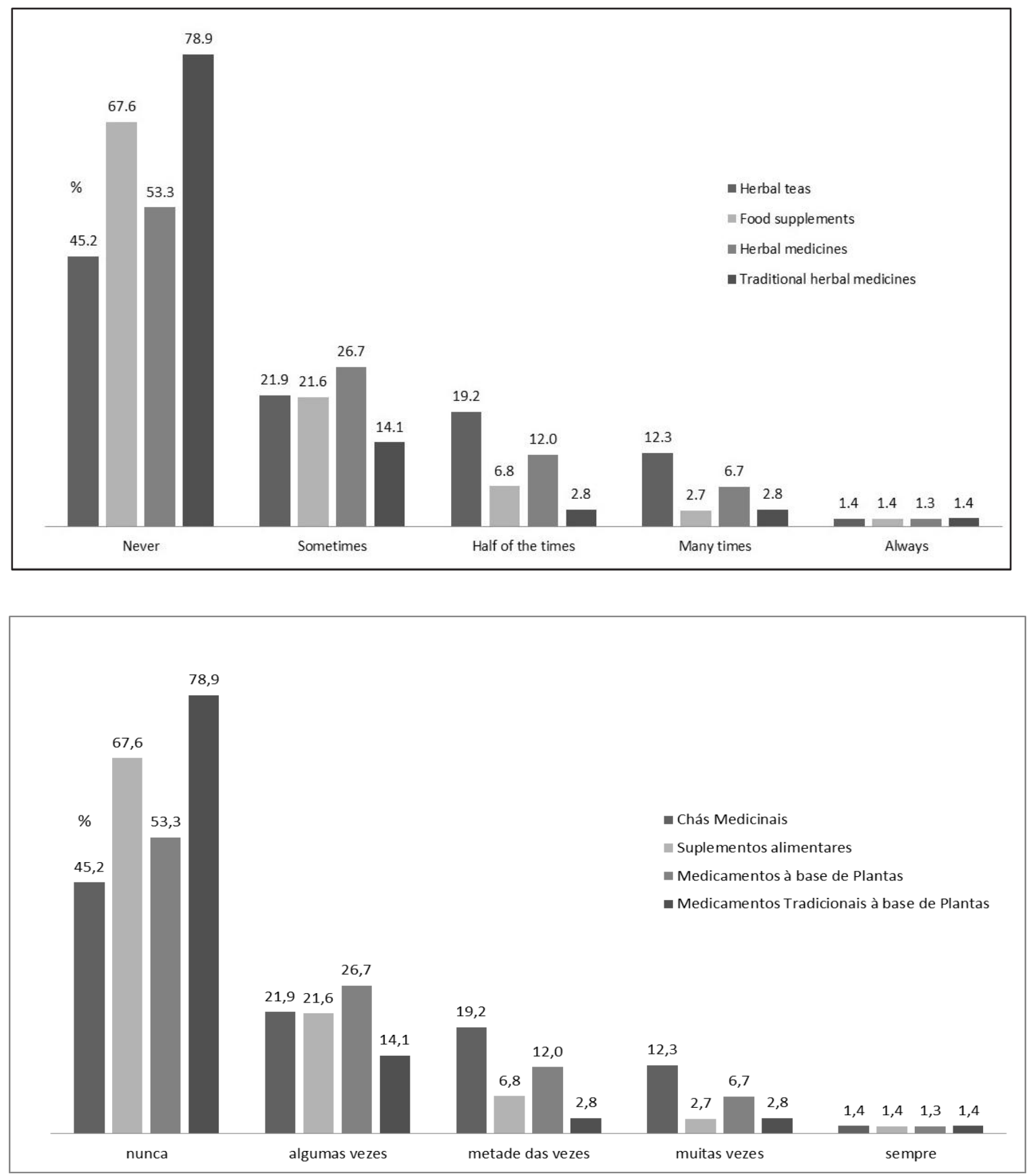

Figure 5/ Figura 5 - Adherence to phytotherapy: frequency of self-consumption of different categories of herbal products by the respondent physicians/ Adesão à fitoterapia: frequência de autoconsumo, de diferentes categorias de produtos à base de plantas, pelos médicos inquiridos. 

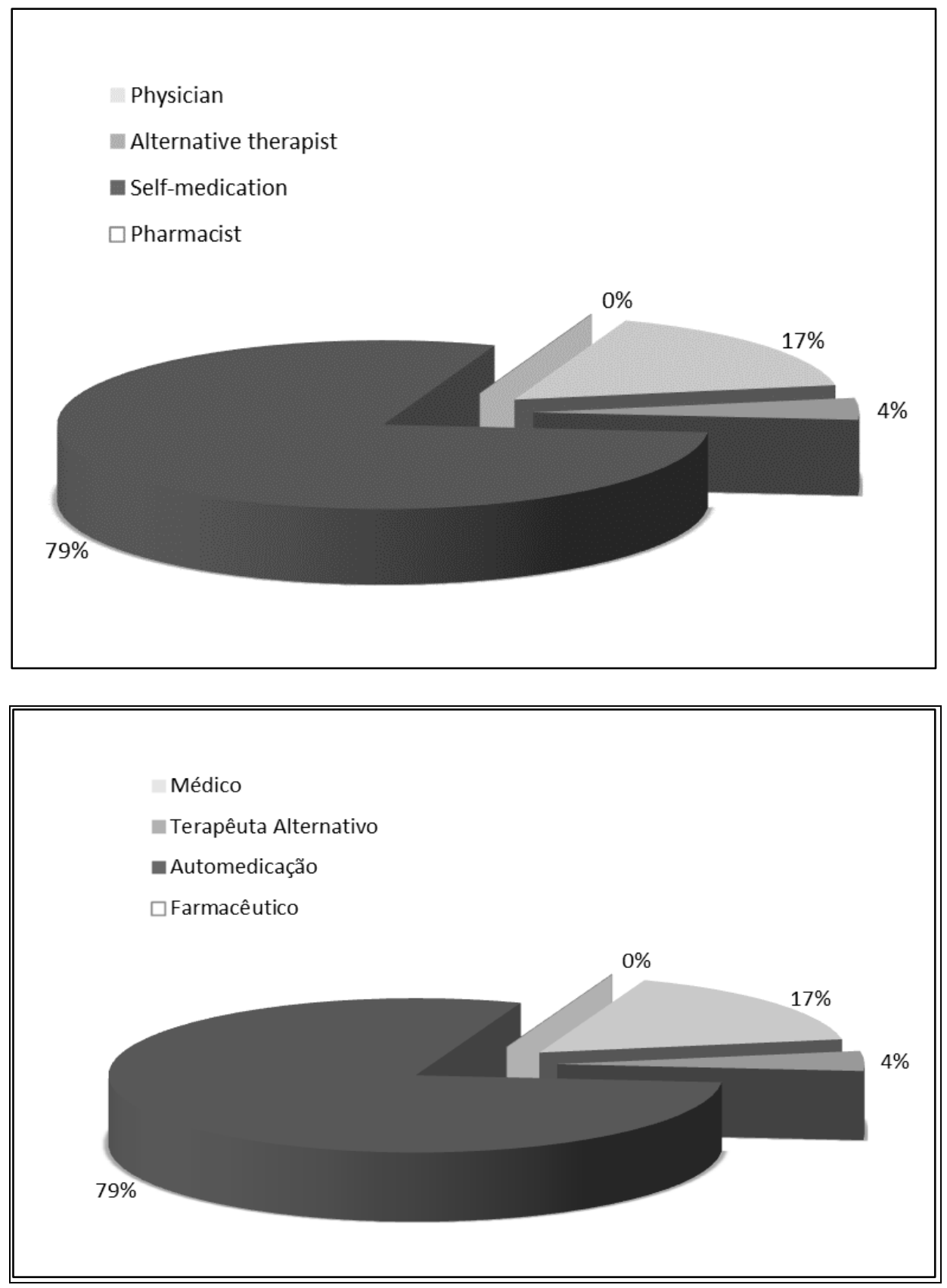

Figure 6/ Figura 6 - Adherence to phytotherapy: frequency of self-consumption of herbal products by self-medication or under the guidance of other health professionals by respondent physicians/ Adesão à fitoterapia: frequência de autoconsumo de produtos à base de plantas por automedicação ou sob orientação de outros profissionais de saúde, pelos médicos inquiridos 

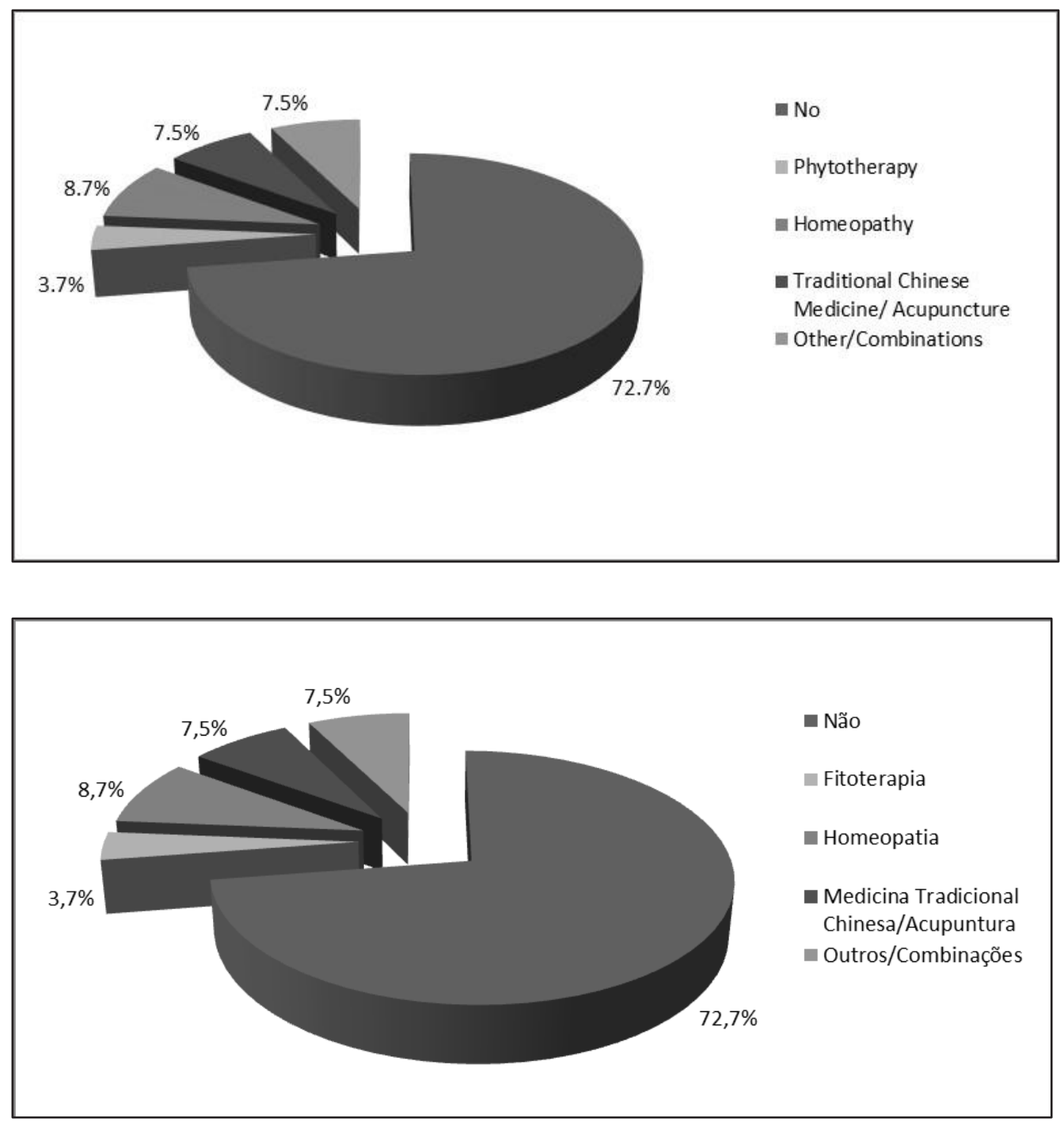

Figure 7/ Figura 7- Adherence to phytotherapy: frequency of recommendation to the patients, of unconventional therapy that uses herbal medicinal products, by respondent physicians/ Adesão à fitoterapia: frequência de recomendação aos seus pacientes, de terapia não convencional que utilize produtos/medicamentos à base de plantas, pelos médicos inquiridos 
It was found that most physicians do not recommend or prescribe herbal products to their patients until there is little benefit from this use (Figure 3). Most doctors also never recommended herbal medicines as well as THMP, botanical supplements or medicinal teas.

The adherence to phytotherapy by the physician facilitates the dialogue with the patient who wants to treat or who uses medicinal plants in some way, either by self-medication or by indication of non-professionals, leading to therapeutic benefit for the patient. On the other hand, if physicians are not aware of the option of using the basic principles of rational phytotherapy in their patients' therapy, they fail to understand and appropriately counsel patients about plant extracts (26). Despite the discrepancy between the practice of using these products and their own use, with regard to medicinal teas $(12.3 \%$ of doctors have taken many times, and $7.7 \%$ have prescribed many times, Figures 4 and 5) there is consistency between prescription and their own use. On the other hand, it is observed the practice of self-medication by physicians, which would be expected, because they are health professionals (Figure 6).

Comparing the results of this study with other studies, a poor adherence to phytotherapy was found, as in other countries. This may be related to the relatively late appearance of specific legislation on herbal products in relation to the legal community framework that emerged in 2001 (4), as only in 2004 the new category of THMP appeared in Europe (6), transposed into the Medicines Regulatory Statute in Portugal approximately 10 years ago (in 2006) (27).

Poor adherence may also be related to the lack of medical education in phytotherapy at the undergraduate level in Medicine, currently designated as an Integrated Master of Medicine. The lower adherence by the doctors with the degree of master, relative to specialists can evidence a distance from a specific area of therapeutic approach, which is not integrated in an educational model that contemplates this area of knowledge.

We found that adherence to use was higher among USF physicians compared to USCP. This linkage may reveal the logistic context, but also the larger proportion of younger age groups, which may influence the health professional's perception and attitudes $(23,28)$.

\section{Conclusion}

Phytotherapy is a therapeutic area still with little acceptance by doctors in spite of increasing adherence by other health professionals. The lack of acceptance / adherence and consequent non-use of herbal products may be based on the perception of lack of information
Este aspeto é particularmente importante já que a maioria dos pacientes não comunica ao médico assistente, tão-pouco o médico questiona o paciente acerca da utilização de produtos à base de plantas (21). Além disso, estes produtos estão cada vez mais disponíveis no mercado farmacêutico, ervanárias, hipermercados, sendo acessíveis para a automedicação $(2,22)$, podendo ser inapropriadamente utilizados pelos pacientes.

O médico assume um papel com elevado poder de decisão em relação à utilização da fitoterapia pelo paciente, sendo esta influência otimizada pela confiança e suporte da relação médico-paciente. Como este profissional é entendido pela população como verdadeiro, apresentando poder legítimo na prescrição de medicamentos, os valores e conhecimento que o médico passar sobre o uso dos medicamentos ou até dos suplementos à base de plantas, serão entendidos pelo paciente, e no momento de optar por seguir o seu conselho, o posicionamento do médico em relação aos mesmos, se refletirá na ação do paciente (2). A discrepância existente entre a adesão médica e a recomendação da utilização de plantas medicinais na terapêutica pode ter como base a carência de conhecimento, tal como verificado em estudos de vários autores (20,23-25). Os resultados da presente pesquisa, também confirmam que a fraca adesão médica, na base da escassa utilização de produtos à base de plantas, poderá ter a ver com a carência de conhecimentos.

Foi constatado que a maior parte dos médicos não recomenda ou prescreve produtos à base de plantas aos seus pacientes considerando até haver pouco beneficio nessa utilização (Figura 3). A maior parte dos médicos também nunca recomendou medicamentos à base de plantas, assim como MTBP, suplementos ou chás medicinais.

A adesão à fitoterapia por parte do médico é facilitadora de um diálogo com o paciente que se quer tratar ou que utiliza plantas medicinais de alguma forma, ou por automedicação ou por indicação de não profissionais, levando ao beneficio terapêutico para o paciente. Por outro lado, se os médicos não estão conscientes da opção de usar na terapêutica dos seus pacientes os princípios básicos da fitoterapia racional, falham no entendimento e aconselhamento médico sobre extratos de plantas (26). Apesar da discrepância entre a prática de utilização destes produtos e a utilização própria no que se refere aos chás medicinais $(12,3 \%$ dos médicos já tomaram, contra $7,7 \%$ de prescrição, Figuras 4 e 5, verifica-se coerência entre a prescrição e a utilização própria. Por outro lado, assiste-se à prática de automedicação por parte dos médicos, o que aliás seria de esperar, porque se tratam de profissionais de saúde (Figura 6).

Comparando o resultado deste estudo com outros estudos, verifica-se que há uma fraca adesão à fitoterapia, também noutros países. Esta situação poderá estar relacionada 
about these products, as well as on legislative aspects. These aspects may underlie a lack of training, namely the lack of phytotherapy teaching / learning in medical schools, thus the majority of doctors lack knowledge and adherence. This training may reduce the risk of uninformed use of medicinal plants. The physician, like all health professionals, has the responsibility of promoting the conscious use of herbal medicine, clarifying to the patient the appropriate use of medicines and herbal supplements that can be used for self-medication, as well as to prescribe herbal medicinal products, either of traditional use or of well-established use, as a therapeutic alternative, or inform about the options, if that is the patient's preference.

\section{Conflit of Interest}

None Declared com o aparecimento relativamente tardio de legislação específica dos produtos à base de plantas, relativamente ao enquadramento legal comunitário que surgiu em 2001 (4), pois apenas em 2004 aparece na Europa a nova categoria de MTBP (6), transposta apenas há 10 anos (em 2006) para Portugal no Estatuto de Medicamento (27).

A fraca adesão pode estar também relacionada com a falta de educação médica em fitoterapia no nível do curso de graduação em Medicina, atualmente designado de Mestrado Integrado de Medicina. A menor aderência por parte dos médicos com o grau de mestre, pode evidenciar um afastamento duma área específica de abordagem terapêutica, por não integração de um modelo educativo que contemple esta área de conhecimento. Verificamos que a adesão à utilização foi maior entre os médicos das USF em comparação com os da USCP $(p=0,014)$. Esta adesão pode revelar o contexto logístico, mas também a maior proporção de faixas etárias mais jovens, que pode influenciar a perceção e atitudes do profissional de saúde $(23,28)$.

\section{Conclusão}

A fitoterapia é uma área terapêutica ainda pouco aceite por parte dos médicos apesar da crescente adesão de outros profissionais de saúde. A falta de aceitação / adesão e consequente não utilização de produtos à base de plantas pode ter como base a perceção de desconhecimento destes produtos, assim como de aspetos legislativos. Estes aspetos podem estar subjacentes a uma carência de formação, nomeadamente pela inexistência de ensino/aprendizagem em fitoterapia nas Faculdades de Medicina, predominando o tipo de médico que não adere e não conhece. Esta formação poderá evitar o risco na utilização não informada de plantas medicinais. O médico tem, como todos os profissionais de saúde, a responsabilidade de promover o uso consciente da fitoterapia, esclarecendo o paciente sobre a boa utilização dos medicamentos e suplementos à base de plantas de venda livre que podem ser usados em automedicação, assim como prescrever um medicamento à base de plantas, quer de uso tradicional, quer de uso bem estabelecido, ou informar de alternativa terapêutica, caso seja essa a preferência do paciente.

\section{Conflito de interesses}

Os autores declaram ausência de conflito de interesses 


\section{References/ Referências}

1. Shaw D, Graeme L, Pierre D, Elizabeth W, Kelvin C. Pharmacovigilance of herbal medicine. J Ethnopharmacol [Internet]. Elsevier Ireland Ltd; 2012;140(3):513-8.

2. Pereira da Silva A. Bioética e Fitoterapia - Diagnóstico de uma situação e seu enquadramento Ético. Universidade de Lisboa; 2002.

3. INFARMED, Conselho de Ministros. Decreto-Lei-176 Estatuto do Medicamento - Legislação Farmacêutica Compilada - INFARMED [Internet]. 2006 p. $1-250$.

4. Comissão Europeia. Directiva 2001/83/CE. Jornal Oficial das Comunidades Europeias 2001 p. 5-35.

5. Comunidade Europeia. DIRECTIVA 2004/27/CE DO PARLAMENTO EUROPEU E DO CONSELHO. J Of da União Eur. 2004;L 136/34.

6. Comissão Europeia. Directiva 2004/24/CE do Parlamento Europeu e do Conselho de 31 de Março de 2004. 2004 p. 85-90.

7. European Medicines Agency. Herbal medicinal products [Internet]. [cited 2016 Mar 1].

8. Barnes J. Quality, efficacy and safety of complementary medicines: Fashions, facts and the future. Part II: Efficacy and safety. Br J Clin Pharmacol. 2003;55(4):331-40.

9. Comissão Europeia. DIRECTIVA 2002/46/CE DO PARLAMENTO EUROPEU E DO CONSELHO de 10 de Junho de 2002 relativa à aproximação das legislações dos Estados-Membros respeitantes aos suplementos alimentares. Directiva 2002 p. 51-7.

10. Comissão Europeia. Regulamento (CE) N. o 1170/2009. L 3142009 p. 36-42.

11. Bilia AR. Herbal medicinal products versus botanical-food supplements in the European market: state of art and perspectives. Nat Prod Commun. United States; 2015 Jan;10(1):125-31.

12. Costa MC, Marques A, Resendes I, Santos I, Lima A, Rosário N, et al. Estudos de suplementos alimentares à base de plantas no mercado português. Riscos e Aliment. 2012;Suplemento(3):11-8.

13. Geraldes M, Salgueiro L. Interacções entre preparações à base de plantas medicinais e medicamentos. Rev Fitoter. 2009;9(1):5-22.

14. Krenn L, Bilia AR, Costa MC, Hook I, Steinhoff B, Wegener T. Now Ginkgo - 10 years after Cimicifuga? Phytomedicine [Internet]. Elsevier GmbH.; 2013;21(1):98-9.

15. Izzo AA, Hoon-Kim S, Radhakrishnan R, Williamson EM. A Critical Approach to Evaluating Clinical Efficacy, Adverse Events and Drug Interactions of Herbal Remedies. Phytother Res [Internet]. 2016;30(5):691-700.

16. Mendes E, Herdeiro MT, Pimentel F. O Uso de Terapêuticas à Base de Plantas por Doentes Oncológicos. Acta Med Port. 2010;901-8.

17. Delgoda R, Ellington C, Barrett S, Gordon N, Clarke N, Younger N. The practice of polypharmacy involving herbal and prescription medicines in the treatment of diabetes mellitus, hypertension and gastrointestinal disorders in Jamaica. West Indian Med J. 2004;53(6):400-5.

18. Nlooto M. Views and experiences of healthcare professionals towards the use of African traditional, complementary and alternative medicines among patients with HIV infection: the case of eThekwini health district, South Africa. BMC Complement Altern Med [Internet]. BMC Complementary and Alternative Medicine; 2015;15(1):170.

19. Mehta DH, Gardiner PM, Phillips RS, McCarthy EP. Herbal and dietary supplement disclosure to health care providers by individuals with chronic conditions. J Altern Complement Med. 2008;14(10):1263-9.

20. Clement YN, Williams AF, Khan K, Bernard T, Bhola S, Fortuné M, et al. A gap between acceptance and knowledge of herbal remedies by physicians: the need for educational intervention. BMC Complement Altern Med. 2005;5:20.

21. Giveon S., Liberman N, Klang S, Kahan E. A survey of primary care physicians' perceptions of their patients' use of complementary medicine. Complement Ther Med [Internet]. 2003;11(4):254-60.

22. Wetzel MS, Eisenberg DM, Kaptchuk TJ. Courses involving complementary and alternative medicine at US medical schools. JAMA. 1998;280(9):784-7.

23. Ameade EPK, Amalba A, Helegbe GK, Mohammed BS. Herbal medicine : a survey on the knowledge and attitude of medical students in Tamale, Ghana. 2015;3(1):1-8.

24. Canna JG, Rajesh KJ. Influence of knowledge on attitude and practice of health care professionals regarding use of herbal medicines in a tertiary care teaching hospital : a cross-sectional survey. URPBS. 2012;3(3):1215-9.

25. Xu S, Levine M. Medical residents' and students' attitudes towards herbal medicines: a pilot study. 2008;15(1):9-12.

26. Furst R, Zundorf I. Evidence-Based Phytotherapy in Europe: Where Do We Stand? Planta Med. 2015;962-7.

27. Decreto-Lei-176. Ministério da Saúde. Diário da República, 1.a série 2006 p. 6297-383.

28. Akan H, Izbirak G, Kaspar ECC, Kaya CACA, Aydin S, Demircan N, et al. Knowledge and attitudes towards complementary and alternative medicine among medical students in Turkey. BMC Complement Altern Med [Internet]. 2012;12:115. 